\title{
Comparison of the Nasal Olfactory Organs of Various Species of Lizardfishes (Teleostei: Aulopiformes: Synodontidae) with Additional Remarks on the Brain
}

\author{
L. Fishelson, ${ }^{1}$ D. Golani, ${ }^{2}$ B. Galil, ${ }^{3}$ and M. Goren ${ }^{1}$ \\ ${ }^{1}$ Department of Zoology, Tel Aviv University, Tel Aviv 69978, Israel \\ ${ }^{2}$ Department of Evolution, Systematic, and Ecology, The Hebrew University of Jerusalem, Jerusalem 91130, Israel \\ ${ }^{3}$ National Institute of Oceanography, Shikmona, Haifa 31080, Israel
}

Correspondence should be addressed to L. Fishelson, fishelv@post.tau.ac.il

Received 7 March 2010; Revised 23 May 2010; Accepted 10 August 2010

Academic Editor: Marilyn Renfree

Copyright ( $) 2010$ L. Fishelson et al. This is an open access article distributed under the Creative Commons Attribution License, which permits unrestricted use, distribution, and reproduction in any medium, provided the original work is properly cited.

\begin{abstract}
The olfactory organs of lizardfishes (Synodontidae) are situated in two capsules connected to the outside by incurrent and excurrent openings. The olfactory epithelium is in form of petal rosettes each composed of lamellae and a rephe, and bear olfactory receptor neurons, supporting cells and cells with kinocillia. The dimension of rosettes and lamellae, as well as the number of lamellae, increase with growth of the fish; until in adult fish these parameters remaine constant, species specific. In adult Synodus spp. and Trachinocephalus myops the rosettes are 3.5-4.0 mm long, with 5-8 lamellae, whereas in Saurida spp. they are $8.0 \mathrm{~mm}$ and possess up tp 22 lamellae. The number of ORN ranges from 2,600 on the smaller lamellae to 20,000 on the largest ones. The number of ORN $/ \mathrm{mm}^{2}$ of olfactory is ca. 30,000 in Saurida spp. Thus the rosettes of S. macrolepis with 20 lamellae possess a total of ca. 170,000 ORN, whereas those of Sy. variegatus and T. myops with the average of six lamellae possess only ca. 50,000-65,000 ORN. The olfactory nerves lead from the rosettes to the olfactory balbs situated on the olfactory lobes. The differences among the species in olfactory organs are discussed in correlation with their distribution.
\end{abstract}

\section{Introduction}

Sensory organs responsible for olfaction in fish have been studied for almost two centuries [1-9, 20, and literature therein]. Reviews of these studies were published by Doty [10], Hansen and Zielinski [11], and Valentinçic [12], and the evolution of these sensory organs was discussed by Zeiske and Hansen [13]. Several contributions to our understanding of the specificity of odor recognition by the olfactory receptor neurons (ORNs) have also been made $[14,15]$. Olfaction in fish is mainly carried out within a pair of nasal cavities in the ethmoidal part of the head, which in ditrematous fishes connects with the outside via two openings, the incurrent and recurrent nares. The olfactory epithelium (OE) develops from two ectodermic thickenings in front of the embryonic neural tube $[13,16]$, and early on during embryogenesis this anlage differentiates into several types of ORN: Type I dendrites bearing cilia on their apical surfaces attached to a knob-like swollen part; Type II sensory microvilli-bearing cells, often also with cilia on their exposed surfaces; Type III, a special subtype of ciliated neurons, namely rod cells, which present an adhered group of cilia of a single neuron. Recently, a new type of the so-called "crypt cells" has been described in sharks [17] and teleosts [18], in which the sensory cilia are situated in a neuronal crypt. Elongating at their basal region, the ORNs form fibers that jointly constitute the olfactory nerves (ONs). In addition to the ORN, the OE includes basal cells, situated close to the basal membrane of this epithelium, from which the other cell types can regenerate, as well as supporting cells. Water is transported in and out of the nasal capsules by kinocilia situated within the $\mathrm{OE}$ or by constrictions of the muscles around the capsules. In most fishes, the sensory epithelium forms petal-like folds (lamellae) in the nasal cavities found on either side of a raphe, and together forming a sensory rosette [19]. Each rosette lies within a cover of connective tissue, all surrounded 
by the nasal capsules. The ORN and supporting cells extend over the surface of these lamellae. In numerous fishes, the base of the epithelium extends below the skin, forming a miniature sack that is also possibly involved in the transport of water across the sensory cells.

Fish with few lamellae on the rosettes as, for example, blennies [20] are termed microsmatic while those with numerous lamellae are termed macrosmatic. Most authors agree that the number of lamellae and the number of sensory cells on them reflect the sensory acuity of the fish $[19,21]$. The signals received by the cells of these organs are carried via the $\mathrm{ON}$ to the olfactory bulb $(\mathrm{OB})$, from where they continue via a pair of olfactory tracts (OTs), to the olfactory lobes of the forebrain [20]. The position of OB relative to the sensory epithelium differs in different fishes; in some, for example, cyprinids, they are closely attached to the olfactory epithelium [22], whereas in others, as in cichlid fishes [20], the $\mathrm{OB}$ is closely attached to the olfactory lobe of the forebrain. The length of the ON differs accordingly; in fishes with the $\mathrm{OB}$ attached to the olfactory epithelium the ONs are almost invisible [22], whereas in those with the $\mathrm{OB}$ attached to the olfactory lobes, the ONs are long and the OTs are not prominent [20-22]. The present study compares the form and cytology of the nasal rosettes of 12 species of lizardfishes (Synodontidae) from the Red Sea, eastern Mediterranean Sea, and near Hawaii and Taiwan in the Pacific Ocean (Table 1) with additional brief remarks on their brain. All these are benthic predatory fishes, usually resting on or partly concealed in the soft sediment, with only the upper head part, eyes, and nostrils exposed. They are predators, ambushing passing fish and crustaceans.

\section{Material and Methods}

The lizardfishes for the present study were collected at depths of 10-300 $\mathrm{m}$ using various types of nets (hand nets, standing gill nets, beam trawl). Some of the specimens were fresh collected whereas others were given from goodpreserved museum collections (see Acknowledgment). All studied fish are listed in Table 1. To allow better penetration of fixatives into the nasal organs and brain, the nasal organs were partly exposed in the freshly collected specimens during fixation. For light microscopy (LM), the samples were fixed in 10\% neutral formaldehyde (Frutarom, Israel) or $70 \%$ ethanol, and the sampled organs were embedded in Paraplast, from which $8 \mu \mathrm{m}$ thick sections were made and stained with crysol violet (Sigma) or Ehrlich Hemtoxylineosin. These sections were studied with a Leider microscope equipped with a digital camera (Motic) attached to a PC. For electron microscopy (EM), some samples were fixed in $10 \%$ neutral formaldehyde or 3\% glutaraldehyde (Fluka). For transmission electron microscopy (TEM), the samples were postfixed in osmium tetroxide and embedded in Epon. The ultra thin sections of these blocks were then stained with uranyl acetate and lead citrate and studied with an electron microscope (JEOL-K 9). For scanning electron microscopy (SEM), the formaldehyde-fixed samples were passed along ascending grades of ethanol, saturated with $\mathrm{CO}_{2}$, critically point dried with Balzer 11120, gold dusted (Sputter Counter of Polard, E5100), and studied with a scanning electron microscope (JSM840A). The various measurements were executed with a Digmatic microcaliber (Mitutoyo Comp.). Counts of the ORN were executed with the aid of a dissecting microscope and SEM micrographs and included 10 sites each of $1000 \mu \mathrm{m}^{2}$ from each organ (lamella). Also the volume of the nasal capsules was calculated from microcaliber data according to $\pi r^{3}$. Similarly, the relative dimensions of the olfactory bulb, forebrain, and optic tectum were calculated as a sphere, however, being ventrally flat, the results were divided by two.

\section{Results}

3.1. Olfactory Rosettes. Except for the genus Trachinocephalus, all the heads of the studied lizardfishes are pointed, with a terminal mouth that extends back to behind the eyes (Figures 1(a), 1(b), and 1(c)). The head dorsa of Trachinocephalus and Synodus spp., beginning from a transverse supraoccipital ridge, is naked and rugose, bearing an intricate and species-specific pattern of ridges, interspersed with lines of pores of mucus cells (Figure 1(d)). In Saurida spp., the dorsal cover of scales extends over the head. The nares of the studied fishes are situated close to the head apex, dorso lateral on the head. The incurrent and recurrent openings of each nare are in close proximity; the incurrent opening displays a small skin flap (Figure 1(e)). The volume of the nasal capsules was ca. $3.0-5.5 \mathrm{~mm}^{3}$; they are situated between the head apex and eyes (Figure 1(f)) supported by the premaxilla and palatal bones, as well as an embedding dense mucous layer.

In each nasal capsule, the olfactory epithelium forms the lamellations that constitute the olfactory rosettes described in various fishes. The olfactory rosettes can be divided into several groups by their gross morphology [23]. The rosettes are attached ventrally, exposing dorsally the free endings of the olfactory lamellae (Figure 1(h)). The smallest rosettes, of ca. $1.4( \pm 0.3) \mathrm{mm}$ long, were seen in Trachinocephalus myops (Figure 1(i)), and the largest, $7.5( \pm 1.2) \mathrm{mm}$, in $S$. macrolepis (Figure 2(a)). In Saurida spp., the height of the lamellae is equal or almost equal to the side attached to the raphe whereas in Synodus spp. and Trachinocephalus myops the attached side is often narrower than the free end (Figure 2(b)). Each lamella is formed by two layers of a pseudo stratified epithelium, between which blood capillaries and the neural filaments of the sensory cells are situated within the connective tissue. The neural filaments join and continue to form a bundle in the raphe (Figure 2(c)). Exiting the nasal capsules, these bundles continue as two ca. $0.5 \mathrm{~mm}$ thick olfactory nerves that extend toward the $\mathrm{OB}$, on the forebrain (Figure 2(d) and insets 1, 2).

The major intraspecific and interspecific differences in the dimensions of the rosettes and the number of lamellae in each rosette of the studied lizardfish were found in fish of different standard body-length $\left(S_{L}\right)$ and in different species. For example, Saurida macrolepis of $90 \mathrm{~mm} S_{L}$ bear 8 lamellae on each side of the raphe; those of $110 \mathrm{~mm} S_{L}$ bear 12 lamella; of $140( \pm 5) \mathrm{mm}_{L}$ bear14 lamella; of $180( \pm 8) \mathrm{mm} S_{L}$ bear16 lamellae, and in fish of $220( \pm 20) \mathrm{mm} S_{L}$ each rosette bears 
TABLE 1: Lizardfishes studied, locality of origin, and standard length $\left(S_{L}+\mathrm{SD}\right.$ in mm.).

\begin{tabular}{|c|c|c|c|c|}
\hline Species name \& author & Site of collection & No. fish studied & $S_{L}(\mathrm{~mm})$ & Sex \\
\hline Saurida elongata (Temminck \& Schlegel, 1846) & Taiwan & 7 & $140( \pm 20)$ & $\mathrm{M}+\mathrm{F}$ \\
\hline Saurida gracilis (Quoy \& Gaimard, 1924) & Red Sea, Kosrae & 8 & $160( \pm 9)$ & $M+F$ \\
\hline Saurida macrolepis (Tanaka, 1917) & Mediterranean, Red S. & 20 & $280( \pm 80)$ & $\mathrm{M}+\mathrm{F}$ \\
\hline Saurida nebulosa (Valenciennes, 1850) & Hawaii & 1 & 109 & $\mathrm{~F}$ \\
\hline Saurida tumbil (Bloch, 1795) & Red Sea & 7 & $220( \pm 60)$ & $\mathrm{M}+\mathrm{F}$ \\
\hline Synodus dermatogenis (Fowler, 1912) & Tonga Is., Seychelles, Mozambique & 8 & $90( \pm 50)$ & $\mathrm{M}+\mathrm{F}$ \\
\hline Synodus falcatus (Waples \& Randall, 1989) & Hawaii & 1 & 56 & M \\
\hline Synodus indicus (Day,1873) & India (Kerala) & 1 & 126 & $\mathrm{~F}$ \\
\hline Synodus kaianus (Guenther, 1880) & Hawaii & 2 & 155,202 & $\mathrm{~F}$ \\
\hline Synodus saurus (Linnaeus, 1758) & Mediterranean Sea & 4 & $180( \pm 15)$ & $\mathrm{M}+\mathrm{F}$ \\
\hline Synodus variegatus (Lacepode, 1803) & Red Sea, Philippines, Natal (S. Africa) & 26 & $150( \pm 80)$ & $M+F$ \\
\hline Trachinocephalus myops (Forster, 1801) & Red Sea, Hawaii & 8 & $175( \pm 45)$ & $\mathrm{M}+\mathrm{F}$ \\
\hline
\end{tabular}

(no differences were exposed between the sexes); SD, standard deviation.

$19( \pm 1)$ lamellae on each side of the raphe. In the three genera the lamellae also differ in their form (Figure 1(i) and Figures 2(a) and 2(b)).

A similar pattern was observed in S. tumbil. In contrast, in $S$. gracilis (of the same genus) of $65 \mathrm{~mm} S_{L}$ the rosettes bear 10 lamellae on each side of the raphe, and specimens of $102 \mathrm{~mm} S_{L}$ bear 22 lamellae (Figure 2(e)). In Synodus spp. and T. myops, larger fishes of $180( \pm 30) \mathrm{mm} S_{L}$ featured only $7.0( \pm 2)$ lamellae on each side. One exception was $S y$. falcatus from Hawaii, in which a specimen of $56 \mathrm{~mm} S_{L}$ and a rosette of $0.8 \mathrm{~mm}$ in length already bore 9 lamellae. In Sy. dermatogenis from Tonga the rosettes differ from all the other species in being round, with a miniature central raphe surrounded by 12 lamellae. Table 2 summarizes the data on the rosettes of the studied species.

3.2. Olfactory Lamellae. Each lamella of the olfactory rosette is triangular in shape, with the base attached to a central raphe. The largest and widest-based lamella were observed in $200 \mathrm{~mm} S_{L}$ Saurida macrolepis, $1.0 \mathrm{~mm}$ long and $0.4 \mathrm{~mm}$ wide at the base, and situated along the central part of the raphe; while the narrowest lamellae were observed in Synodus variegatus, being $1.0-1.3 \mathrm{~mm}$ long and $0.3 \mathrm{~mm}$ wide at the base. In all instances, the smallest lamellae were always found at the posterior end of the raphe. The cells forming the $\mathrm{OE}$ on the various sites of the lamellae differ in the structures of their exposed membranes. For example, over the apical narrow frame, $60.0-70.0 \mu \mathrm{m}$ wide, the exposed membranes of nonsensory cells are covered by the typical microridge (fingerprint) patterns (Figure 2(f)), described for skin surfaces and sensory lamellae of numerous fish groups $[20,21]$. In T. myops such microridged epithelium covers the posterior part of the frame only, while the rest bears cells with kinocilia.

Across this zone, on either side of the lamellae, extends a ca. $90-100.0 \mu \mathrm{m}$ wide zone with numerous microvillar ORNs, each with 90-100 2-3 $\mu \mathrm{m}$ long microvilli. At the end of this zone the microvillar cells intermingle with cilia-bearing ORNs, differing in the form and pattern of distribution among the various species studied. For example, in Synodus spp. and T. myops the ORNs form lines of single-isolated or densely-packed cells, each with 10-20 cilia; similar cells are also partly situated between the microvillar cells (Figure 2(g)). In Saurida macrolepis and S. tumbil, below the zone of microvilli extends a zone of ORNs, each with 3-5 cilia, $0.2-0.25 \mu \mathrm{m}$ thick and $6.0-8.0 \mu \mathrm{m}$ long, forming a mosaic at $8-10 \mu \mathrm{m}$ intervals from each other (Figure 2(h)). In Saurida spp. other ORNs are irregularly distributed between such ORNs, with cilia $0.15-0.20 \mu \mathrm{m}$ thick and 6-7 $\mu \mathrm{m}$ long (Figure 2(i)). Below this zone extends a zone with sparsely distributed ORNs and a dense cover of kinocilia, more delicate and longer than the cilia of the ORNs (Figure 2(j)).

3.3. Number of Olfactory Receptor Neurons on Lamellae. The density of ORN on the lamellae differs among the various species studied. Calculations show that in S. macrolepis the surface of the largest lamellae covers ca. $0.24 \mathrm{~mm}^{2}$ and of the smallest that covers $0.05 \mathrm{~mm}^{2}$. As the largest measured rosettes of $S$. macrolepis bear ca. 20 lamellae, on each side of the raphe, with an average area of $0.15 \mathrm{~mm}^{2}$, such rosettes will cover a total of ca. $6.0 \mathrm{~mm}^{2}$ surface, in turn covered by ORN and supporting cells. Counts show that in Saurida, on the largest lamellae ca. 14,000-20,000 ORN can be found, and around 1,200-1,600 on the smallest lamellae. As the average number of observed ORN on such lamellae was ca. $30 / 1000 \mu \mathrm{m}^{2}$, this brings the total of ORN on all lamellae of S. gracilis to ca. 105,000 and of S. macrolepis to ca. 180,000, whereas in the genera Synodus and Trachinocephalus it is no higher than ca. 70,000.

In all the species studied the so-called olfactory lashes [24] or olfactory rods, as well as unique olfactory vela, were frequently found on several sites of the lamellae (Figure 3(a)). These are in fact groups of cilia from a single ORN united into one organelle, round or flat, covered externally by a mucous envelope. The number of such rods or vela per site differs among the species. 

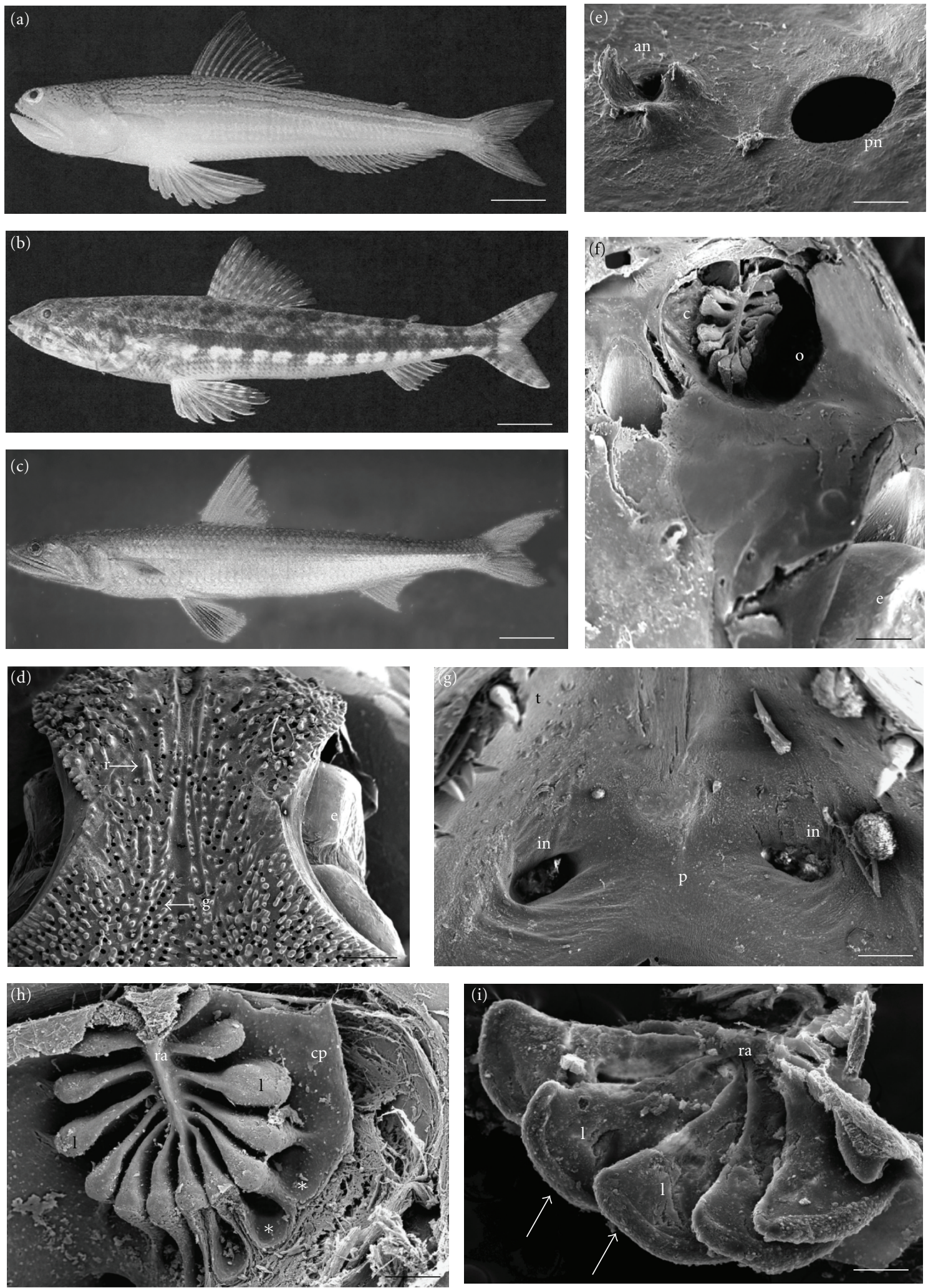

Figure 1: The genera of the studied lizardfishes, the olfactory nares, and olfactory rosettes. (a) Trachinicephalus myops; (b) Synodus variegatus; (c) Saurida tumbil, scale bar $=1.5 \mathrm{~cm}$; (d) dorsal skull surface of Trachinocephalus myops, scale bar $=4 \mathrm{~cm}$; (e) external nares of Sy. variegatus, scale bar $=0.8 \mathrm{~mm}$; (f) open nasal capsule of Sy. saurus, scale bar $=3 \mathrm{~mm}$; (g) internal nares of Sy. variegatus, scale bar $=$ $1.5 \mathrm{~mm}$; (h) olfactory rosette of Sy. kaianus, scale bar $=4 \mathrm{~mm}$; (i) One site of the olfactory rosette of T. myops, scale bar $=0.8 \mathrm{~mm}$ : an, anterior nare; c, olfactory capsule with rosette; cp, inner cover of olfactory capsule; e, eye; g, lines of mucus gland cells; in, inner nares; 1 , olfactory lamellae; o, deeper part of the olfactory capsule; $p$, anterior part of the palate; pn, posterior nare; r, ridges on the head; ra, raphe of rosette; $t$, teeth of upper jaw; star, passages for water transport; arrows, swollen margins of olfactory lamellae. 

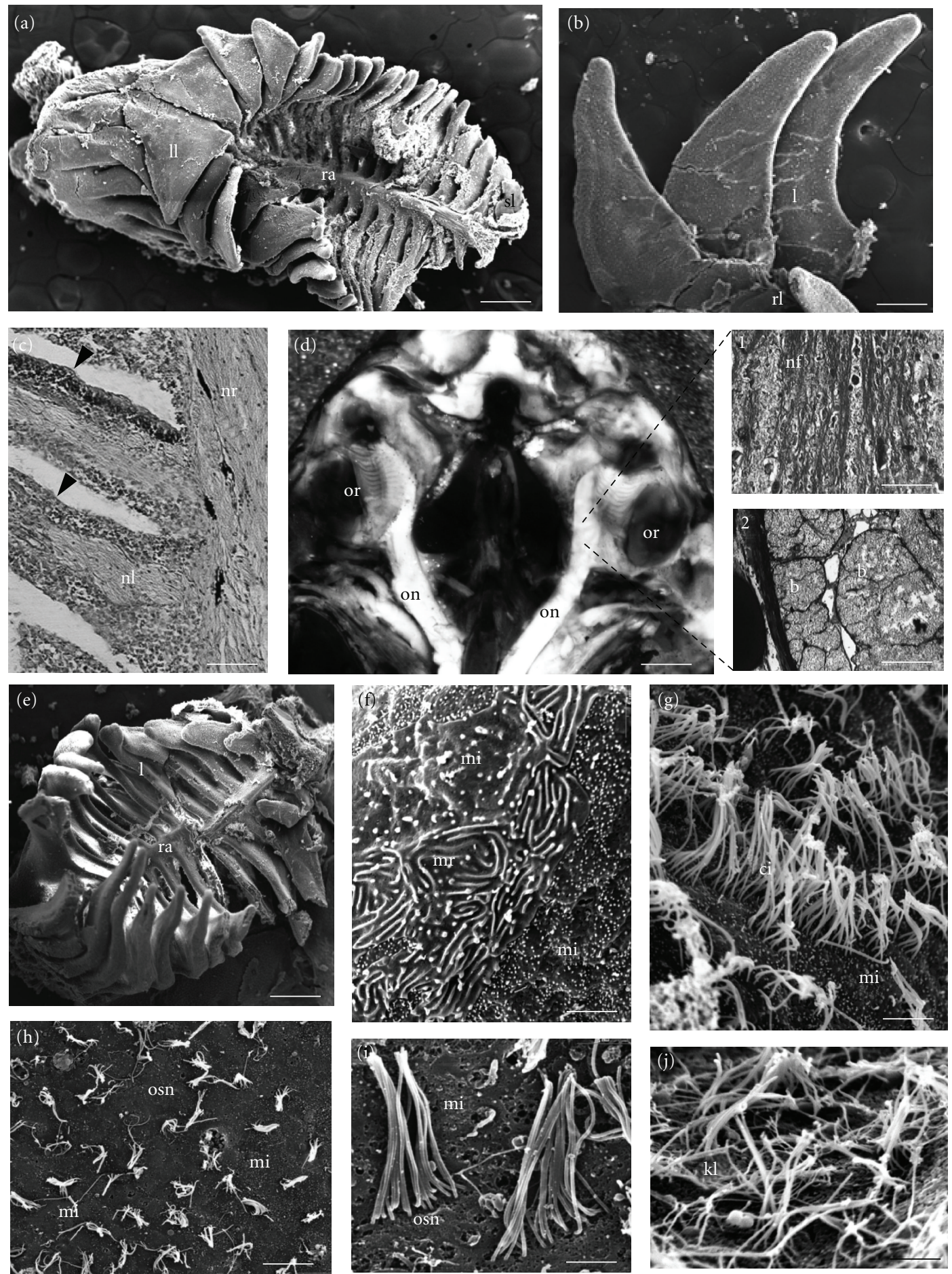

FIGURE 2: Olfactory rosettes and their lamellae with olfactory neurons. (a) The olfactory rosette of Saurida macrolepis, scale bar $=0.8$ mm; (b) lateral aspect of isolated lamellae of Synodus variegatus, scale bar $=100 \mu \mathrm{m}$; (c) longitudinal section of lamellae of S. gracilis, featuring olfactory fibers and nerve in the raphe, scale bar $=60 \mu \mathrm{m}$; (d) exposed brain, olfactory nerves and rosettes of $S$. tumbil, scale bar $=2.4 \mathrm{~mm}$ (inset 1 , longitudinal section of the $\mathrm{ON}$; inset 2, cross section of the same; scale bars $=100 \mu \mathrm{m}, \mathrm{LM}$ ); (e) olfactory rosette of $S$. gracilis, scale bar $=1 \mathrm{~mm}$; (f) the rim of an olfactory lamella of Sy. variegatus, scale bar $=8 \mu \mathrm{m}$; (g) rows of ciliated cells on lamellae of the same, scale bar $=4 \mu \mathrm{m}$. (h) mosaic of ORN on a lamellae of S. tumbil, scale bar $=12 \mu \mathrm{m}$; (i) isolated ORN of Trachinocephalus myops, scale bar $=2.6 \mu \mathrm{m}$; (j) Kinocilia-cells at the base of olfactory lamellae of S. macrolepis, scale bar $=4 \mu \mathrm{m}$. b, boundless of neural filaments; c, cilia of ORN; kl, kinocilia; l,olfactory lamellae; ll, largest lamella; mi, microvillar cells; mr, microridges on cell surfaces; nf, neural fibrille; nl, nerve-bundles in olfactory lamellae; $\mathrm{nr}$, nerve branch in the raphe; on, olfactory nerve; or, olfactory rosettes; osn, cilia of olfactory sensory neurons; sl, smallest lamellae; ra, raphe of rosette; triangles, sensory epithelium (C and insets, LM; all other SEM). 

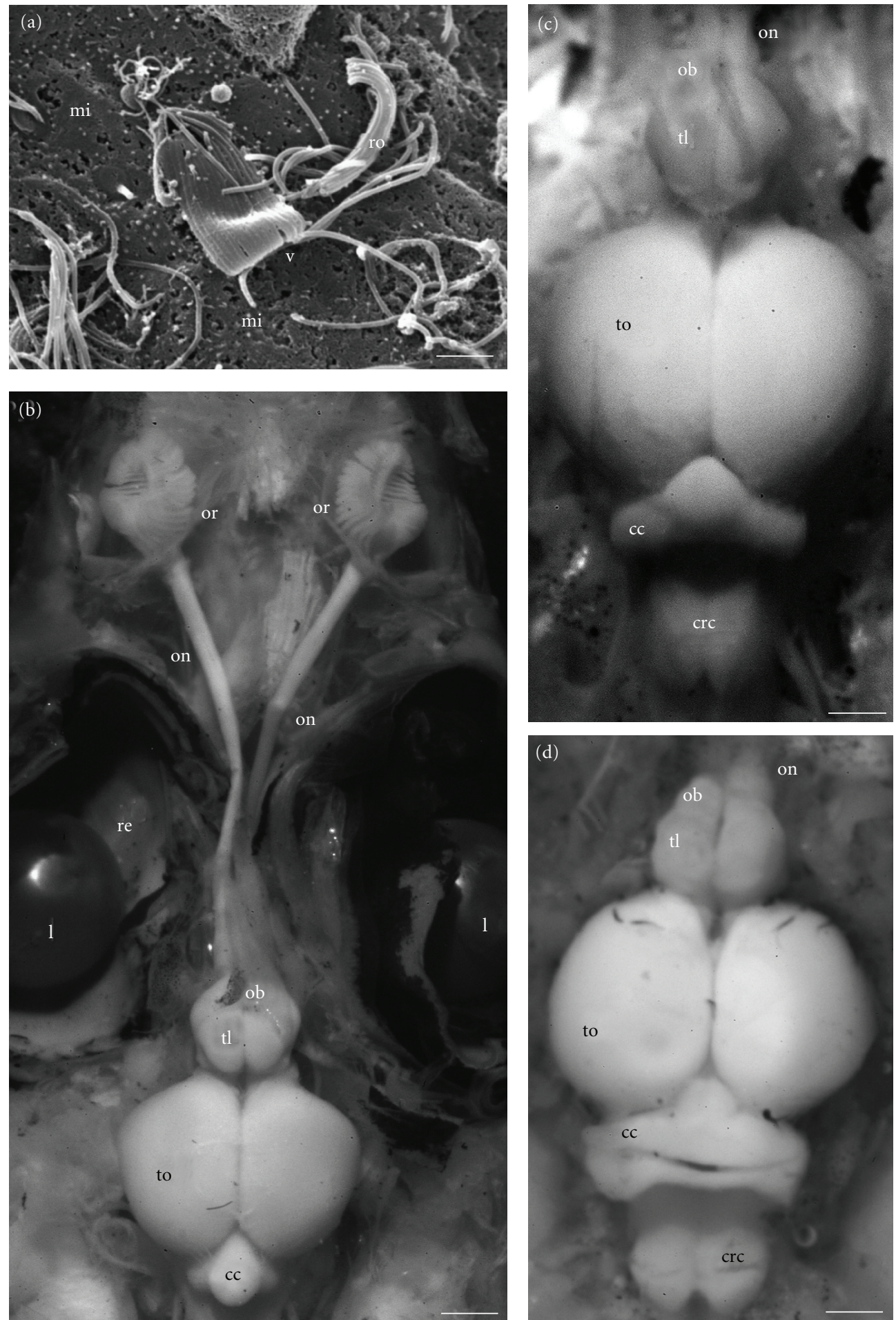

FIGURE 3: SEM of the brain and receptor cells. (a) Rod receptor and compound "vela" on lamellae of Trachinocephalus myops, scale bar = $2.5 \mu \mathrm{m}$; (b) brain and olfactory rosettes of Saurida tumbil, scale bar $=3.5 \mathrm{~mm}$; (c) brain of T. myops, scale bar = $1 \mathrm{~cm}$; (d) ibid of Synodus variegatus, scale bar $=1 \mathrm{~cm} . \mathrm{cc}$, cerebellum; crc, corpus cerebellis; 1 , eye lens; mi, microvillar cells; ob, olfactory bulb; on, olfactory nerve; or, olfactory rosettes; re, retina (part); ro, rode-like compound cilia; tl, telencephalon; to, optic tectum; v, "vela-like" compound cilia. 
TABLE 2: Dimensions of rosettes, number of lamellae, and approximate number of ORN on the largest of them (size in mm) in the studied lizardfishes.

\begin{tabular}{|c|c|c|c|c|c|c|}
\hline Species & Largest fish $\left(S_{L}\right)$ & Smallest fish $\left(S_{L}\right)$ & Largest rosette & Smallest rosette & No. of lamellae** & No. of ORN* \\
\hline Saurida elongata & 140 & 102 & 4.4 & 3.0 & $20( \pm 2)$ & 14,000 \\
\hline Saurida gracilis & 160 & 48 & 6.0 & 3.0 & $36( \pm 2)$ & 16,000 \\
\hline Saurida macrolepis & 230 & 90 & 6.5 & 3.2 & $40( \pm 10)$ & 16,800 \\
\hline Saurida nebulosa & 109 & $\mathrm{n} / \mathrm{a}$ & 4.5 & 3.2 & $20( \pm 2)$ & 14,000 \\
\hline Saurida tumbil & 245 & 98 & 7.5 & 4.4 & $28( \pm 8)$ & 20,000 \\
\hline Synodus dermatogenis & 139 & 31 & 2.9 & 1.6 & $14( \pm 7)$ & 12,000 \\
\hline Synodus falcatus & 56 & $\mathrm{n} / \mathrm{a}$ & 0.8 & $\mathrm{n} / \mathrm{a}$ & 18 & 5,000 \\
\hline Synodus indicus & 126 & $\mathrm{n} / \mathrm{a}$ & 2.6 & $\mathrm{n} / \mathrm{a}$ & 16 & 10,000 \\
\hline Synodus kaianus & 202 & 155 & 4.8 & 4.0 & $18( \pm 4)$ & 12,000 \\
\hline Synodus saurus & 180 & 130 & 4.7 & 3.0 & $16( \pm 4)$ & 12,600 \\
\hline Synodus variegatus & 200 & 87 & 5.0 & 2.2 & $14( \pm 4)$ & 7,600 \\
\hline Trachinocephalus myops & 175 & 128 & 4.8 & 2.8 & $12( \pm 5)$ & 10,200 \\
\hline
\end{tabular}

** on both sides of the raphe; * on the largest lamella; n/a, not applicable.

3.4. Remarks on the Olfactory Bulb and Telencephalon. As stated earlier, two strong ONs extend from the olfactory rosettes to the olfactory bulb $(\mathrm{OB})$ attached to the forebrain. The olfactory tracts of fibers that extend from the $\mathrm{OB}$ to the brain are thus concealed (Figure 3(b)). The present study revealed that the dimensions of the $\mathrm{OB}$ and telencephalon (TE) in the lizardfishes are relatively small in comparison to the optic tectum. For example, the relatively small OB of Synodus variegatus is ca. $14 \%$ the size of the TE, and the TE is only $5.4-5.8 \%$ in volume that of the optic tectum; in Saurida gracilis the OB is $6.2 \%$ of the optic tectum, and in $S$. tumbil the $\mathrm{OB}$ is $8.8 \%$ of the optic tectum. Differences were also observed in the dimensions and forms of the brain in the various species (Figure 3(c) and 3(d)).

\section{Discussion}

Studies of olfaction in fish have shown that the various ORNs are specialized for detection of various multiple odorants, and the sensitivity of the organ can be compared to that of the retina $[11,15]$. Atema [4] was the first to state that "chemical pictures may not be essentially different from visual, mechanical, sound, or electrical pictures in containing specific information" (p. 61). In most instances, the studies on olfaction have focused on a single species of a selected taxon, and only a few researches have compared the organization of these organs in a group of species from the same taxonomic unit, as, for example, Livingstone [25] in flatfishes, Fishelson [21] in cichlids, and Gon and Fishelson [20] in blennies.

The studied lizardfishes are predators that, like other larger predators, use visual signals to detect passing prey, predominantly other fish. However, the results have shown that, in addition, the lamellation of the olfactory epithelium and the resulting receptor rosettes with ORN are relatively well developed. For example, in blennies, which feed on benthic algae or small crustaceans, the rosettes possess 3-4 lamellae, and each rosette is $2.0 \times 12.5 \mathrm{~mm}$ in size whereas in the studied synodontid fish the number of lamellae on each side of the rosettes varies from 7 to 22 , the central ones of which attain a maximum size of $7.5 \times 3.0 \mathrm{~mm}$. This increase in size of the rosettes and number of lamellae in larger specimens, as observed with the growth of the fish (Table 2), may increase the olfactory acuity of the fish $[1,19]$. The small sizes of olfactory rosettes in blennies and their larger sizes in synodontids suggest that the sense of smell does not play an important role in the life of the former, unlike in the latter group. The lizardfishes are active hunters, and it is possible that smell is involved not only in food detection.

Calculation of the apparent number of ORNs on the larger lamellae of the studied fish revealed that in species of the genus Saurida, this number was always higher than in species of the other two genera (Table 2). For example, the highest number of ORN/largest lamellae was 20,000 in S. tumbil, and only 7,600 in Synodus variegatus. Such differences were persistent in all the studied species. Calculated per $\mathrm{mm}^{2}$, it reaches ca. $145,000 \mathrm{ORN} / \mathrm{mm}^{2}$ in S. tumbil, and $45,000 / \mathrm{mm}^{2}$ in Sy. variegatus. A similar phenomenon was previously observed in species of blenny fishes: Salaria pavo possess ca. $55,000 / \mathrm{mm}^{2}$ on the lamellae, whereas Heteroclinus perspicillatus of a similar size possess ca. $117,000 / \mathrm{mm}^{2}$ [20]. These numbers of ORNs in lizardfishes are relatively low compared to the $400,000-500,000 / \mathrm{mm}^{2}$ in Xiphophorus and $460,000 / \mathrm{mm}^{2}$ in Oryzias [20]. The calculated number of ORNs in the largest rosettes of adult $S$. macrolepis with 20 lamellae on each side of the rosette will be ca. 300,000. This large number of ORNs could explain the relatively thick olfactory nerves that extend toward the OB (Figure 3). As argued [24, 26-28], in numerous fishes olfaction is also important in reproduction communication, and it is consequently possible that olfaction is also involved in reproductive behavior in the lizardfishes. In the Gulf of Aqaba, Red Sea (L.F. pers. observ.), several times in the shallow water of the Red Sea more colorful males of Synodus variegatus were occasionally observed to follow on the bottom females with swollen abdomens at a distance of $15-25 \mathrm{~cm}$. It seems that at this stage of reproductive behavior olfactory reception can play an important role. 
However, to determine whether such following is based solely on vision or also on olfactory stimuli, additional field observations and experimental studies are required.

\section{Acknowledgments}

The authors would like to thank Dr. Kwang-Tsao Shao (Taiwan), L. O'Hara and A. Suzumoto (Hawaii), and Dr. Ofer Gon (Ichthyological Museum, Grahamstown, South Africa) for samples of fishes from their museums, and the colleagues and students who helped to collect the fishes in Israel. Thanks are extended to Dr. J. Randall (Hawaii) for permission to use his fish photos from FishBase, to Naomi Paz for her editorial help, to Y. Delarea for help in preparation of the EM sections, and to V. Wexler for help in the artwork. The authors are thankful to the two anonymous reviewers, the remarks of whom contributed to the paper.

\section{References}

[1] H. Kleerekoper, Olfaction in Fishes, Indiana University Press, Bloomington, Ind, USA, 1969.

[2] T. J. Hara, "Olfaction in fish," Progress in Neurobiology, vol. 5, no. 4, pp. 271-335, 1975.

[3] T. J. Hara, "Olfaction and gustation in fish: an overview," Acta Physiologica Scandinavica, vol. 152, no. 2, pp. 207-217, 1994.

[4] T. J. Hara, "Olfactory responses to amino acids in rainbow trout: revisited," in Fish Chemosenses, K. Reutter and B. G. Kapoor, Eds., pp. 32-64, Science Publishers, Enfield, NH, USA, 2005.

[5] J. Atema, "Chemical senses, chemical signals, and feeding behavior in fishes," in Fish Behavior and its Use in the Capture and Culture of Fishes (ICLARM Conference 5), J. E. Bardach, J. J. Magnuson, R. C. May, and J. M. Reinhart, Eds., pp. 57-101, International Center for Living Aquatic Resources Management, Manila, Philippines, 1983.

[6] T. J. Hara and B. S. Zielinski, "Structural and functional development of the olfactory organ in teleosts," Transaction of the American Fishery Society, vol. 118, pp. 183-194, 1989.

[7] M. T. Shipley and M. Ennis, "Functional organization of olfactory system," Journal of Neurobiology, vol. 30, no. 1, pp. 123-176, 1996.

[8] A. Hansen and K. Reutter, "Chemosensory systems in fish: structural, functional and ecological aspects," in The Senses of Fish: Adaptation for the Reception of Natural Stimuli, G. Von der Emde, J. Magdans, and B. G. Kapoor, Eds., pp. 5589, Kluwer Academic Publishers, Dordrecht, The Netherlands, 2004.

[9] K. Reutter and B. G. Kapoor, Fish Chemosenses, Science Publishers, Enfield, NH, USA, 2005.

[10] R. L. Doty, Handbook of Olfaction and Gustation, Marcel Decker, New York, NY, USA, 2nd edition, 2003.

[11] A. Hansen and B. S. Zielinski, "Diversity in the olfactory epithelium of bony fishes: development, lamellar arrangement, sensory neuron cell types and transduction components," Journal of Neurocytology, vol. 34, no. 3-5, pp. 183-208, 2005.

[12] T. Valentinçic, "Olfactory discrimination in fishes," in Fish Chemosenses, K. Reutter and B. G. Kapoor, Eds., pp. 65-85, Science Publishers, Enfield, NH, USA, 2005.

[13] E. Zeiske and A. Hansen, "Development and evolution of the olfactory organ in Gnathostome fish," in Fish Chemosenses,
K. Reutter and B. G. Kapoor, Eds., pp. 1-29, Science Publishers, Enfield, NH, USA, 2005.

[14] J. L. Dynes and J. Ngai, "Pathfinding of olfactory neuron axons to stereotyped glomerular targets revealed by dynamic imaging in living zebrafish embryos," Neuron, vol. 20, no. 6, pp. 1081-1091, 1998.

[15] L. B. Buck, "Information coding in the vertebrate olfactory system," Annual Review of Neuroscience, vol. 19, pp. 517-544, 1996.

[16] H. Breucker, E. Zeiske, and R. Melinkat, "Development of the olfactory organ in the rainbow fish Nematocentris maccullochi (Atheriniformes, Melanotaeniidae)," Cell and Tissue Research, vol. 200, no. 1, pp. 53-68, 1979.

[17] L. Fishelson and A. Baranes, "Ontogenesis and cytomorphology of the nasal olfactory organs in the Oman shark, Iago omanensis (Triakidae), in the Gulf of Aqaba, Red Sea," Anatomical Record, vol. 249, no. 3, pp. 409-421, 1997.

[18] A. Hansen and T. E. Finger, "Phyletic distribution of crypttype olfactory receptor neurons in fishes," Brain, Behavior and Evolution, vol. 55, no. 2, pp. 100-110, 2000.

[19] C. E. Bond, Biology of Fishes, Saunders College Publishing, San Diego, Calif, USA, 6th edition, 1996.

[20] O. Gon and L. Fishelson, "Nasal olfactory organs and olfactory bulbs in Blennies," in Thebiology of Blennies, R. A. Patzner, E. J. Gonçalves, P. H. A. Hastings, and B. G. Kapoor, Eds., pp. 188-213, Science Publishers, Enfield, NH, USA, 2009.

[21] L. Fishelson, "Comparative ontogenesis and cytomorphology of the nasal organs in some species of cichlid fish (Cichlidae, Teleostei)," Journal of Zoology, vol. 243, no. 2, pp. 281-294, 1997.

[22] K. Koterschal, M. J. van Staden, and R. Huber, "Fish brains: evolution and ecological relationships," Journal of Fish Biology, vol. 8, pp. 1-36, 1998.

[23] M. Yamamoto, "Comparative morphology of the peripheral olfactory organ in teleosts," in Chemoreception in Fishes, T. J. Hara, Ed., pp. 39-59, Elsevier, Amsterdam, The Netherlands, 1982.

[24] E. N. Barata, A. V. M. Canario, and E. Melo, "The role of olfaction in fish reproduction: its importance for conservation of littoral fishes," in Behavior and Conservation of Littoral Fishes, V. C. Almada, R. E. Oliveira, and E. J. Gonçalves, Eds., pp. 127-148, ISBA, Lisboa, Portugal, 1998.

[25] M. E. Livingstone, "Morphological and sensory specializations of five New Zealand flatfish species, in relation to feeding behavior," Journal of Fish Biology, vol. 31, pp. 775-795, 1987.

[26] J. Caprio, "Olfaction and taste in fish," in Comparative Physiology of Sensory Systems, L. Bolis, R. D. Keynes, and S. H. Madrell, Eds., pp. 257-284, Cambridge University Press, Cambridge, Mass, USA, 1984.

[27] E. N. Barata and D. M. Gonçalves, "Communication in Blennies," in The Biology of Blennies, R. A. Patzner, E. J. Gonçalves, P. H. A. Hastings, and B. G. Kapoor, Eds., pp. 353378, Science Publishers, Enfield, NH, USA, 2009.

[28] T. B. Cole and N. E. Stacey, "Olfactory responses to steroids in an African mouth-brooding cichlid, Haplochromis burtoni (Günther)," Journal of Fish Biology, vol. 68, no. 3, pp. 661-680, 2006. 

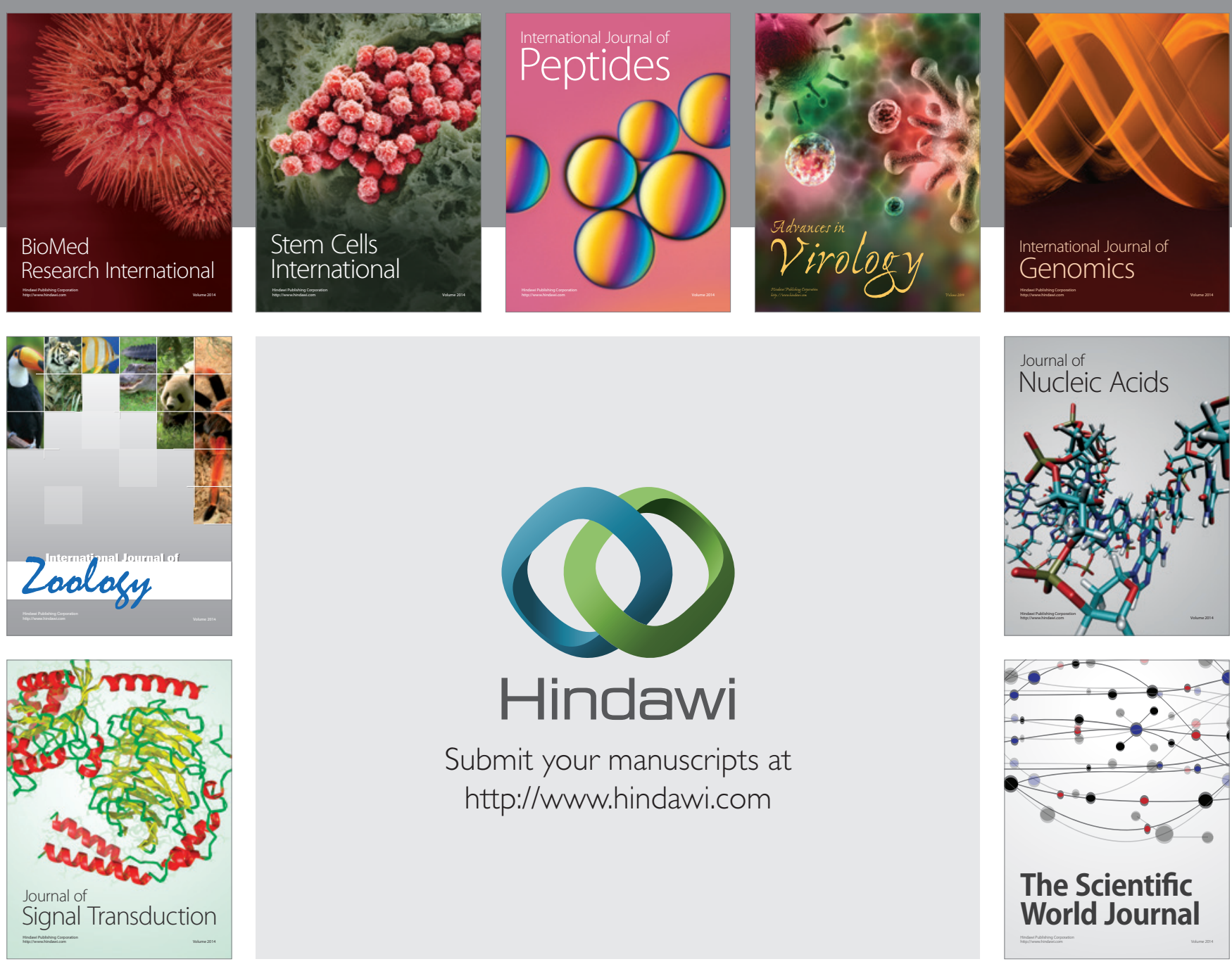

Submit your manuscripts at

http://www.hindawi.com
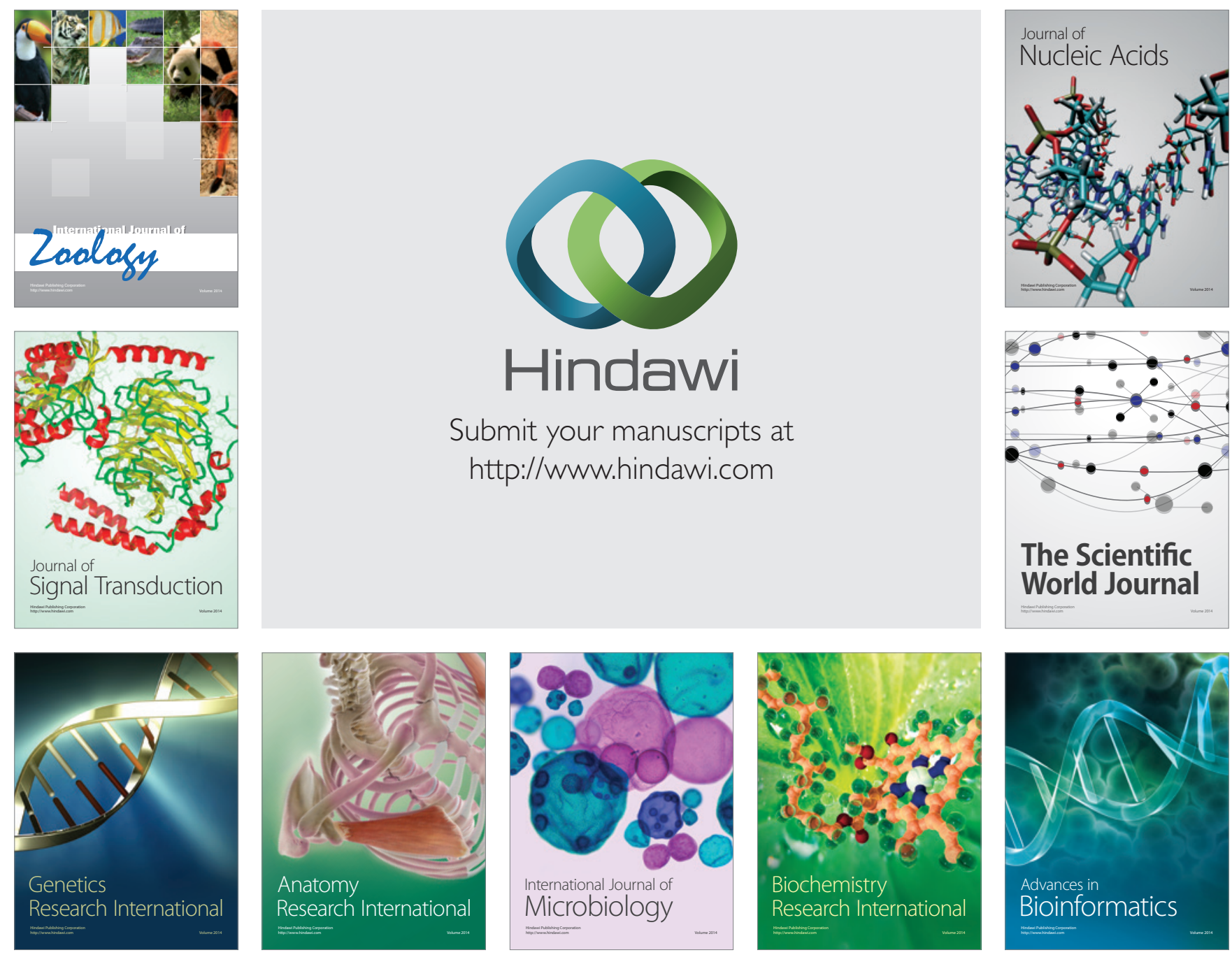

The Scientific World Journal
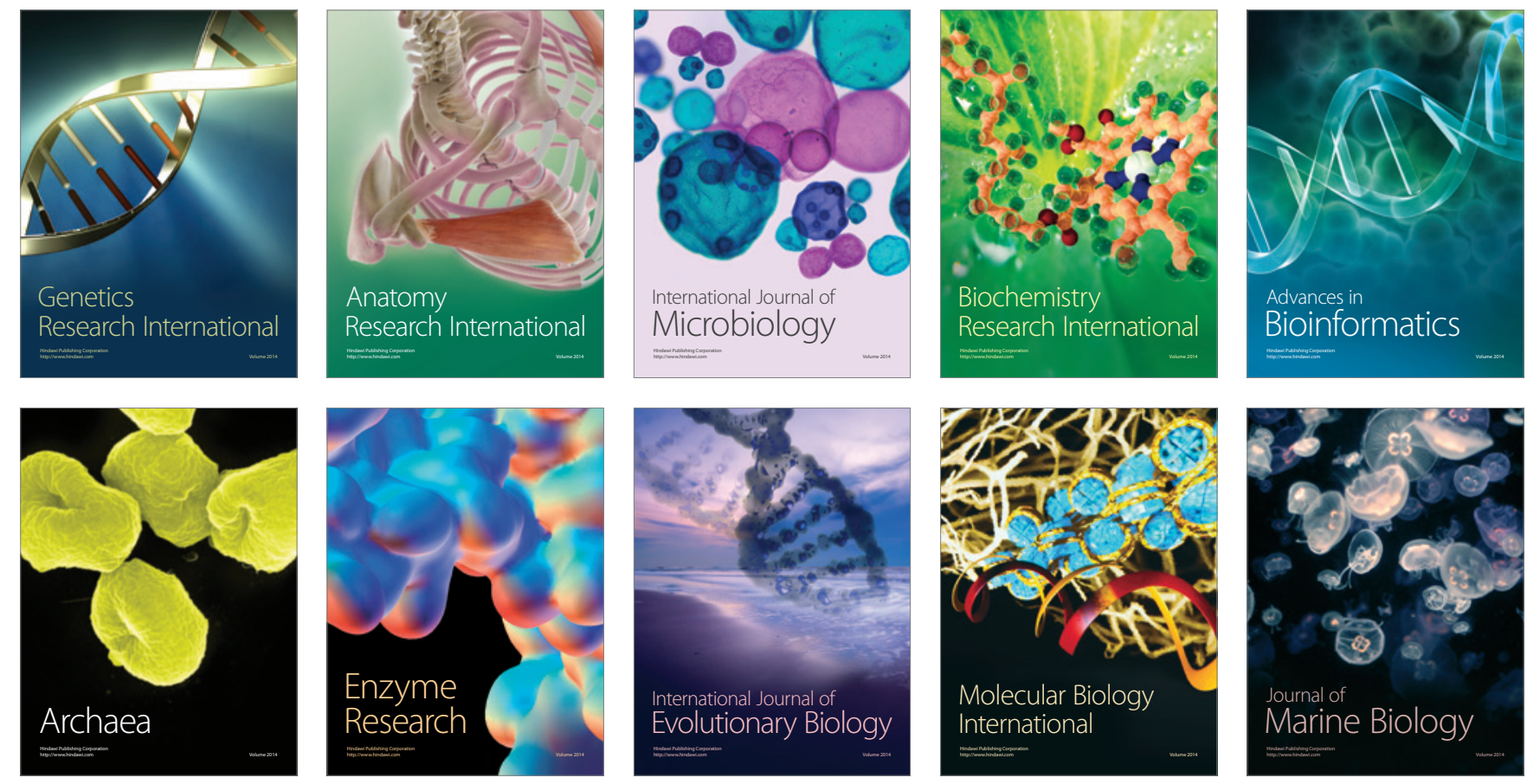